\title{
PERENCANAAN PEMBANGUNAN DAERAH KABUPATEN KEPULAUAN MENTAWAI TAHUN 2012-2017
}

\author{
Meyer Juanti \\ Jurusan Ilmu Politik, Fakultas Ilmu Sosial dan Ilmu Politik, Universitas Andalas \\ Email: MeyeJuanti@gmail.com
}

\begin{abstract}
Abstrak
Dalam dokumen perencanaan RPJMD, pemerintah Kabupaten Kepulauan Mentawai sudah mulai melaksanakan pembangunan melalui program dan visi/misi pembangunan yang ditawarkan oleh Bupati Yudas Sabaggalet, selama kampanye maupun setelah terpilih. Adapun tujuan penelitian ini untuk mengidentifikasi dan menjelaskan persoalan perencanaan RPJMD di Kabupaten Kepulauan Mentawai pada Tahun 2012-2016. Penelitian ini, menggunakan metode kualitatif deskriptif. Hasil penelitian ini menunjukkan bahwa memang perencanaan RPJMD di Kabupaten Kepulauan Mentawai belum sesuai dengan harapan, dapat dijelaskan sebagai berikut: (1) Dalam melibatkan partisipasi masyarakat sudah ada program Musrenbang, akan tetapi masih sering terjadi pro dan kontra antara masyarakat dan pemerintah Kabupaten Kepulauan Mentawai. Proses perencanaan pembangunan masih dalam posisi pendekatan politik, dikarenakan terdapat visi/misi kepala daerah yang dijadikan sebagai kepentingan politik. Adanya ketimpangan kebijakan perencanaan pembangunan yang cenderung atau lebih mengarah pada pendekatan Top-down.
\end{abstract}

Kata Kunci : Perencanaan ; Pembangunan ; RPJMD.

\begin{abstract}
In planning documents RPJMD, the government of Kabupaten Kepulauan Mentawai has begun to implement development through the program and Development Vision/mission offered by Regent Jude Sabaggalet, during the campaign and after being elected. This research, using qualitative methods of descriptive. The results of this study indicate that it was planning RPJMD in Kabupaten Kepulauan Mentawai has not been by following per under the expectations, it can be explained as follows: (1) in involving community participation there is already a program Musrenbang, but still often occurs the pros and cons between the community and government district. Kepulauan Mentawai. The process of development planning is still in the position of political approach because there is the vision/mission of the regional head that used as political interest. There is an inequality of a development planning policy that tends or more leads to a Top-down approach.
\end{abstract}

Keywords: Planning ; Development ; RPJMD

\section{PENDAHULUAN}

Di negara berkembang, termasuk Indonesia perencanaan pembangunan mempunyai peranan yang sangat besar sebagai alat untuk mendorong dan mengendalikan proses pembangunan secara lebih cepat dan terarah. Adapun unsur/aktor yang terlibat dalam perencanaan pembangunan dari dalam adalah para pemimpin atau elit pemerintah dan juga masyarakat atau elit lokal pimpinan dari suatu wilayah atau negara, seperti Presiden/wakil, para gubernur, bupati, walikota, DPR atau DPRD, LSM maupun tokoh adat atau kepentingan lain. Ditingkat lokal atau daerah para gubernur, bupati, walikota, para peengusaha, kelompok elit, DPRD semua itu adalah aktor yang berpengaruh dalam memainkan perencanaan pembangunan. Dalam hal ini, membuktikan bahwa 
pembangunan tidak hanya berfokus pada pemerintah pusat tetapi dari pemerintah daerah ikut mengambil bagian dalam urusan wajib untuk melancarkan pembangunan yang dilaksanakan di daerahnya masing- masing secara mandiri sesuai dengan peraturan otonomi daerah tentang urusan pemerintah. Dari uraian tersebut, dapat diartikan bahwa rencana pembangunan yang banyak diterapkan

Begitu juga halnya di negara Indonesia. Perencanaan pembangunan di negara Indonesia tidak lepas dari persoalan dan tantangan dapat dilihat melalui penelitian yang diteliti oleh Adriani Ginting dkk (1) . Jurnal Wacana (2016). Peneliti menjelaskan bahwa daya saing menjadi salah satu tujuan pembangunan yang krusial karena berkaitan dengan kemampuan suatu daerah dalam menarik tenaga kerja yang terampil dan investasi baik dari dalam maupun luar negeri.

Penelitian dari Herendhika Lukiswara (2). JIAP (2016. Dalam penelitian ini, peneliti menghadirkan sesuatu yang berbeda dari penelitian yang lain. Peneliti menjelaskan permasalahan pada tahapan penyusunan rancangan awal RPJMD adalah kurang seimbangnya penggunaan pendekatan perencanaan pembangunan dan belum adanya penyelesaian masalah pembangunan sampai keakar-akarnya. Selanjutnya permasalahan pada tahapan penyusunan rancangan RPJMD terkait dengan hubungan antara perencana dengan administrator.

Kemudian kasus pembangunan daerah yang diteliti oleh Aziz muslim (3). Jurnal Aziz Muslim (2017), Peneliti menjelaskan bahwa pembangunan bukan sekedar meningkatkan pertumbuhan ekonomi dan pendapatan nasional (GNP) serta terpenuhinya kebutuhan dasar masyarakat, tetapi yang lebih penting lagi adalah pada upaya meningkatkan kualitas manusia agar dapat meningkatkan partisipasi secara nyata dalam berbagai aktifitas kehidupan untuk mendorong terciptanya kegiatan produktif yang bernilai tinggi.

Daerah Kab. Kep. Mentawai merupakan salah satu daerah otonom yang melaksanakan perencanaan pembangunan daeah. Faktanya dalam proses pelaksanaan program perencanaan pembangunan di daerah Kab. Kep. Mentawai masih belum terealisasi sesuai dengan tujuan yang di inginkan, karena melihat beberapa visi/misi perencanaan pembangunan yang ditetapkan dalam dokumen program RPJMD. Visi yang ditetapkan adalah terwujudnya masyarakat kepulauan mentawai yang maju, sejahtera dan berkualitas.

Rencana pembangunan di daerah Kab. Kep. Mentawai sudah dimulai sejak Tahun 1999. Pemerintah daerah Kab. Kep. Mentawai sudah menjalankan beberapa proyek pembangunan. Namun, rencana pembangunan pada waktu itu tidak sesuai dengan harapan masyarakat daerah Kab. Kep. Mentawai mengenai peningkatan kualitas hidup, karena fokus pembangunan hanya mengarah pada pembangunan fisik. Walaupun pembangunan kantor-kantor rumah sakit dan infrasturktur itu baru bisa diakatakan melimpah, namun ide-ide bagi pendekatan mengenai cara peningkatan Sumber Daya 
Manusia (SDM) masih sangat minim, masalah disektor kritis seperti pendidikan, pemeliharaan kesehatan dan ekonomi nyaris tidak diurusi.

Bupati Yudas Sabaggalet juga menyampaikan tentang masih kurangnya SDM di daerah Kab. Kep. Mentawai, berikut penjelasannya:

Saat ini 23 persen penduduk belum mengenyam pendidikan atau tidak tamat SD.

"Kami ingin penduduk Mentawai dapat mengenyam pendidikan yang lebih baik agar dapat membangun daerah"

Besarnya potensi SDA yang dimiliki, tentunya menjadi modal yang sangat berharga untuk menjadikan daerah Kab. Kep. Mentawai dan masyarakat bisa maju dan sejahtera. Namun yang menjadi kendala dalam pengelolaan SDA di mentawai adalah adanya keterbatasan SDM yang secara garis besar dipengaruhi oleh masalah minimnya pendidikan.

Fenomena RPJMD di daerah Kab. Kep. Mentawai tersebut memang masih banyak mengalami kendala. Adanya unsur-unsur dari Visi/Misi yang merupakan indikator untuk mengarahkan penyelenggaraan pembangunan daerah selama lima tahun ke depan. Namun, perkembangan pembangunan sejauh ini khususnya di Kabupaten Kepulauan Mentawai, masih belum berjalan dengan optimal. Setiap penyusunan rencana kerja pembangunan daerah yang dilakukan rutin tiap tahun selalu mengalami keterlambatan. Masih adanya miskomunikasi antara Badan Perencanaan Pembangunan Daerah (Bappeda) dengan Dinas-dinas pada saat pelaksanaan asistensi program dan kegiatan. Begitu juga peranan penting untuk sebuah dokumen RPJMD bagi beberapa unit Satuan Kerja Unit Daerah (SKPD) belum menjadi dasar pemikiran dalam penyusunan program dan kegiatannya. Fenomena ini merupakan suatu pelanggaran kewajiban yang seharusnya dapat dipertanggung jawabkan.

Dalam peraturan daerah Kab. Kep. Mentawai telah disampaikan mengenai visi/misi kepala daerah yang terdapat dalam dokumen RPJMD, yaitu Mewujudkan SDM dan pembangunan infastrukur. Namun misi tersebut belum berjalan dengan optimal, terbukti dari hasil evaluasi Rencana Pembangunan Jangka Menegah Daerah Kabupaten kepulauan Mentawai pada Tahun 2011-2016. Indikasinya dapat dilihat dari masih banyaknya infrastruktur fisik dan fasilitas sarana prasarana pendukung lainnya yang belum selesai secara tuntas. Dalam pelaksanaan kebijakan perencanaan pembangunan mengenai visi/misi Kepala daerah yang terdapat dalam dokumen RPJMD untuk meningkatkan SDM dan Infrastruktur seringkali terjadi ketimpangan, karena kebijakan prencanaan pembangunan lebih didominasi oleh eleit politik dan pemerintah Kab. Kep. Mentawai

Berdasarkan fakta persoalan perencanaan RPJMD bahwa Visi/Misi Kepala Daerah masih belum terlaksana sesuai dengan harapan. Dalam perenanaan pembangunan di daerah Kab. Kep. Mentawai masih kurangnya saling koordinasi dan masih sering terjadi miskominakasi antara dinas dengan dinas lainnya maupun dengan masyarakat. 
Masih adanya ketimpangan kebijakan pembangunan mengenai visi/misi kepalah daerah yang terdapat dalam dokumen RPJMD Kab. Kep. Mentawa yang dijadikan sebagai kepentingan politik, masih adanya sengketah lahan/tanah milik masyarakat yang akan dijadikan lahan untuk membangun infrastruktur sampai sekarang tidak diselesaikan dengan kesepakatan. Perencanan pembangunan dibidang infrastrukur yang mengalami kendala, di mana masyarakat daerah Kab. Kep. Mentawai saling bertentangan dan tidak punya kesatuan hati baik dari pihak mayarakat daerah Kab.Kep. Mentawai maupun dari pemerintah daerah Kab. Kep. Menawai itu sendiri. Jadi, berdasarkan uraian latar belakang di atas, maka perumusan masalah yang menjadi fokus penelitian ini adalah: Bagaimana persoalan perencanaan RPJMD Kab.Kep. Mentawai Tahun 2011-2016?

\section{Review Literature}

Perencanaan pada dasarnya merupakan suatu tahapan, cara, teknik atau metode untuk mencapai tujuan yang diinginkan secara tepat, terarah dan efisien sesuai dengan sumber daya yang tersedia. Dengan demikian secara umum perencanaan pembangunan adalah cara atau teknik untuk mencapai tujuan pembangunan secara tepat, terarah dan efisien sesuai dan kondisi negara atau daerah bersangkutan. Sedangkan tujuan pembangunan pada umumnya adalah untuk mendorong proses pembangunan lebih cepat guna mewujudkan masyarakat yang maju, makmur, dan sejahtera. Pentingnya perencanaan karena untuk menyesuaikan tujuan yang ingin dicapai dalam pembangunan dengan sumber daya yang ada serta berbagai alternative lain yang mungkin diperlukan. Kemudian apa dan bagaimana sebenarnya perencanaan pembangunan itu?

Kemudian dalam penyusunan perencanaan pembangunan di Indonesia, didasarkan pada UU No. 25 Tahun 2004 tentang Sistem Perencanaan Pembangunan Nasional. Sistem pembangunan Nasional di Indonesia mencakup lima pendekatan dalam seluruh rangkaian perencanaan. Lima pendekatan perencanaan pembangunan tersebut sesuai dengan UU RI Nomor 25 Tahun 2004 Tentang SPPN, yaitu 1) Pendekatan politik, 2) Pendekatan teknokratik, 3) Pendekatan partisipatif 4) Pendekatan atas-bawah (top-down) dan 5) Pendekatan bawah-atas (bottom-up).

Pertama, pendekatan Teknokratik, Perencanaan yang dilakukan oleh perencanaan Profesional atau lembaga/unit organisasi yang secara fungsional melakukan perencanaan. Kedua, Pendekatan partisipatif, yang melibatkan para pemangku pembangunan (stakeholders) antara lain melalui pelaksanaan Musrenbang. Ketiga Pendekatan politik. Pemilihan langsung dipandang sebagai proses perencanaan karena menghasilkan rencana pembangunan dalam bentuk visi, misi dan program yang ditawarkan Presiden/Kepala Daerah terpilih selama kampanye. Keempat, Top-down, Pada negara dengan sistem perencanaan sentralistik semua keputusan dan kebijakan pembangunan yang penting semuanya ditentukan oleh pemerintah pusat melalui badan perencanaan pembangunan Nasional. Sedangkan pemerintah daerah hanya sebagai pelaksana sebagian dari kebijakan pusat, walaupun pada masing-masing daerah tersebut memiliki Badan Perencanaan. 
Kelima, Pendekatan ini menjelaskan pemerintah daerah mempunyai peranan yang cukup penting di samping kewenangan pemerintah pusat. Pemerintah daerah dibagikan alokasi dana dalam bentuk "block Grand" yang penggunaannya ditetapkan oleh pemerintah daerah melalui badan perencanaan masig-masing.

\section{METODE PENELITIAN}

Dalam penelitian ini, peneliti menggunakan pendekatan penelitian kualitatif dengan alasan, dengan pendekatan penelitiaan kualitatif ini, peneliti lebih leluasa terlibat secara langsung dengan informan atau objek yang akan diteliti, ada sebuah keharusan untuk membangun relasi atau hubungan antara peneliti dengan yang diteliti. Dalam pemahaman penelitian kualitatif, realitas alam sekalipun, dikontruksikan secara sosial, yakni berdasarkan kesepakatan bersama. Kemudian peneliti memilih pendekatan penelitian kualitatif, karena ada suatu prosedur peneitian yang dilakukan secara alamiah sesuai dengan kondisi yang terjadi di lapangan tanpa adanya rekayasa dan jenis data yang dikumpulkan berupa data deskriptif. Kemudian tidak hanya itu penelitian kualitatif adalah suatu pendekatan yang juga disebut pendekatan investigasi karena biasanya peneliti mengumpulkan data dengan cara bertatap muka langsung dan berinteraksi dengan orangorang di tempat penelitian.

\section{HASIL DAN PEMBAHASAN}

Kabupaten Kepulauan Mentawai adalah salah satu kabupaten yang terletak di provinsi Sumatera Barat, Indonesia, dengan ibukota kabupaten Tua P6ejat yang berada di Pulau Sipora. Kabupaten ini dibentuk berdasarkan UU RI Nomor 49 Tahun 1999 dan dinamai menurut nama asli geografisnya. Kabupaten ini terdiri atas 4 pulau besar ditambah pulau-pulau kecil (94 buah). Keempat pulau besar ini adalah Pulau Siberut, Pulau Sipora, Pulau Pagai Utara, dan Pulau Pagai Selatan.

Kabupaten Kepulauan Mentawai merupakan salah satu kabupaten di Provinsi Sumatera Barat dengan posisi geografis yang terletak diantara 0055'00' -3021'00', Lintang Selatan dan 98035'00'-100032'00' Bujur Timur dengan luas wilayah tercatat $6.011,35 \mathrm{~km} 2$ dan garis pantai sepanjang 1.402,66 km. Pusat pemerintahan dari kabupaten Kepulauan Mentawai adalah berada di Tuapejat, sebelah utara dari pulau Sipora. Secara geografis dan administratif, Kabupaten Kepulauan Mentawai terdiri atas 10 kecamatan, 43 desa dan 202 dusun. Kesepuluh kecamatan tersebut adalah sebagai berikut :

Secara topografi, keadaan geografis daerah Kabupaten Kepulauan Mentawai bervariasi antara dataran, sungai, dan berbukit-bukit, dimana rata-rata ketinggian daerah seluruh ibukota kecamatan dari permukaan laut (DPL) adalah 2 meter. Kabupaten Kepulauan Mentawai beribukota di Tuapeijat yang terletak di Kecamatan Sipora Utara dengan jarak tempuh ke kota Padang sepanjang $153 \mathrm{~km}$. Untuk mencapai ibukota Provinsi Sumatera Barat ini harus ditempuh melalui jalan laut. Begitu pula halnya 
transportasi dari masing-masing ibukota kecamatan ke kota Padang ataupun ke ibukota Kabupaten juga harus ditempuh melalui jalur laut.

\section{Gambar 1. Peta Daerah Kab. Kep. Mentawai}

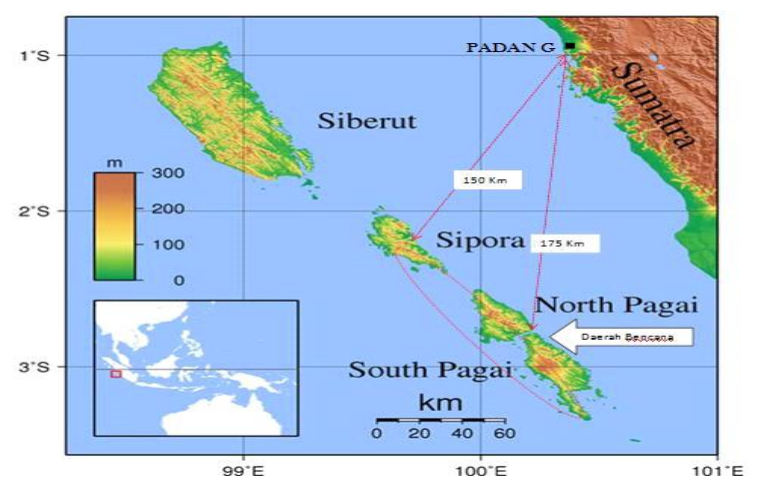

\section{Perencanaan Pembangunan daerah Kab. Kep. Mentawai Tahun 2012-2017}

Perencanaan pembangunan merupakan tahapan awal dalam proses pembangunan sebelum diimplementasikan. Apa lagi sudah ada anjuran dan kerjasama antara pemerintah pusat dan pemerintah daerah agar diusahakan adanya partisipasi masyarakat dalam proses perencanaan pembangunan. Menurut Sjafrizal (2017) pendekatan perencanaan pembangunan partisipatif merupakan suatu kegiatan yang melibatkan masyarakat dalam perencanaan pembangunan untuk mencapai tujuan pembangunan yang terarah dan efisien. Partisipasi masyarakat dalam perencanaan RPJMD dimulai pengimplementasian visi/misi dari kepala daerah yang tentunya visi/misi tersebut harus ada singkronisasi dengan pembangunan di pemerintah pusat.

Keterlibatan (partisipasi) masyarakat dapat melalui kegiatan Musrenbang, seperti yang dilaksanakan oleh Pemerintah daerah Kab. Kep. Mentawai pada Tahun 2016. Pelaksanaan kegiatan Musrenbang ini dihadiri oleh Wakil Gubernur Nasrul Abit, DR. Danis Hidayat Sumadilaga Staf ahli bidang keterbaduan kementerian PU-PR, Komisaris PT. Wiskita Karya, Direkturr Bio Enegi Kementerian SDM. Musrenbang ini telah melalui suatu proses dan tahapan perencanaan yang cukup panjang, dimulai dari Musrenbang Desa, Musrenbang Kecamatan dan Forum Gabungan SKPD yang telah dilaksanakan beberapa waktu yang lalu, dalam rangka menjaring aspirasi masyarakat. Dalam sambutannya, Bupati Yudas Sabaggalet juga menjelaskan perencanaan RPJMD yang akan dilakukan oleh pemerintah sesuai dengan tuntutan masyarakat yang berkeinginan segera untuk dipenuhi. Yudas juga menjelaskan dimasa empat tahun kepemimpinannya telah berhasil meningkatkan Pendapatan Asli Daerah (PAD). Pada tahun ini pemerintah akan meningkatan pelayanan dan fasilitas Infrastruktur, Pendidikan, kesehatan bagi masyarakat.

Dari visi/misi yang telah disampaikan oleh bupati Yudas Sabaggalet, yang terdapat dalam dokumen RPJMD Kab.Kep. Mentawai dapat di artikan bahwa 
perencanaan pembangunan daerah Kab. Kep. Mentawai masih mengarah pada pendekatan politik. Kemudian untuk mengetahui apakah kebijakan visi/misi terebut tidak mengarah pada pendekatan Top-Down, di mana orang yang menjalani dan menyetujui kesepakatan visi/misi tersebut hanya segelintir orang yang mempunyai kepentingan, tidak adanya saling percaya dan kerja sama antara pemerintah daerah dengan masyarakat dalam pelaksanaan kebijakan perencanaan RPJMD sesuai dengan visi/misi yang ada. Untuk itu, perlu juga melihat keterlibatan atau partispasi dari masyarakat baik dalam penentuan visi/misi maupun dalam pelaksanaan visi/misi kepala daerah itu sendiri. Pada bab ini ada 1 poin yang akan peneliti membahas dari temuan lapangan peneliti yaitu, mengidentifikasi dan menjelaskan bagaimana persoalan perencanaan RPJMD di Kab. Kep. Mentawai?

\section{- Pendekatan Partisipatif}

Dari perencanaan RPJMD yang telah diusulkan selama kegiatan musrenbang, nantinya akan di pastikan kembali apa yang menjadi skala prioritas dari perencanaan pembangunan yang akan dilaksanakan kedepannya, seperti yang di ungkapan oleh Bupati Yudas Sabaggalet yang dikutip dari wawancara dengan peneliti sebagai berikut:

..Kegiatan yang menampung partisipasi dari masyarakat sudah sesuai dengan standar yaitu Musrenbang, yang dimulai dari desa, kecamatan, kabupaten, provinsi, kemudian sampai kepusat/Musrenbang Nasional. Dari kegiatan musrenbang itu harus dilihat skala prioritas, karena perencanaan pembangunan yang dilakukan harus ada singkorinasi dari peraturan pembangunan di pusat.

Dapat dijelaskan bahwa pendekatan pembangunan partispatif di daerah Kab. Kep. Mentawai melalui kegiatan musrenbang yang dimulai dari tingkat desa, ditingkat desa tersebut terdiri dari beberapa dusun yang kemudian nantinya hasil dari musrenbang di tingkat desa tersebut akan di rumbukkan kembali melalui musrenbang tingkat kecamatan dan dilanjutkan ditingkat kabupaten. Kegiatan Musrenbang yang dilaksanakan memang harus memperhatikan skala prioritas, karena harus ada singkronisasi perencanaan pembangunan dari pusat. Selama Kegiatan Musrenbang, memang ada beberapa pembangunan yang diajukan oleh masyarakat, harus di rapatkan atau didiskusikan lagi melalui kegaitan musrenbang, apakah perencanaan pembangunan yang diajukan memang sesuai kebutuhan atau hanya sekedar keinginan. Dalam menampung partisipasi masyarakat di daerah Kab. Kep dijelaskan juga oleh Korta Sabeleake dalam dokumen wawancara dengan peneliti:

..Setiap tahun ada musrenbang, ada musrembang ditingkat desa, ada musrenbang ditingkat Kecamatan, musenbang ditingkat Kabupaten. Di mana musrenbang tersebut akan mengundang kepala-kepala dusun. Kepala desa, camat, bupati, wakil bupati, Anggota DPRD, Gubernur dan tokoh Masyarakat. Baru musrenbang ditingkat desa tersebut harus mengundang para kepala dusun untuk mendiskusikan apa yang perlu di usulkan, termasuk mendiskusikan mengenai dana apakah dana 
yang digunakan merupakan dana desa, kabupaten atau pun dana dari provinsi.' Hanya saja yang menjadi permasalahan dalam musrenbang adalah beberapa OPD tidak ikut mengambil bagian dalam kegiatan musrenbang.

Hal ini meyakinkan peneliti bahwa proses perencanaan pembangunan partisipatif memang sudah dilaksanakan di daerah Kab. Kep. Mentawai yang melibatkan berbagai Stakeholders, walaupun dalam proses pelaksanaannya belum maksimal dan masih dalam posisi pendekatan politik serta cenderung mengarah pada pendekatan Top-down. Menurut Kuncoro pendekatan partisipatif merupakan perencanaan pembangunan yang melibatkan pihak yang berkepentingan terhadap pembangunan (Stakeholders), antara lain melalui pelaksanaan Musrenbang.

\section{- Pendekatan Politik}

Pendekatan politik dapat didefinisikan sebagai suatu perencanaan pembangunan yang berupa visi/misi Presiden/Kepalah daerah yang ditawarkan selama kampanye maupun setelah terpilih. Dari temuan peneliti diA lapangan proses perencanaan pembangunan di daerah Kab. Kep. Mentawai masih dalam proses pendekatan politik, karena ada beberapa visi/misi dan komitmen dari Bupati Yudas Sabaggalet yang telah ditawarkan kepada masyarakat selama menjalankan kampanye dan setelah terpilih sebagai kepala daerah dan yang menjadi prioritas utama Bupati Yudas Sabaggalet adalah penigkatan Infrastruktur dan peningkatan SDM. Namun sampai sekarang ini visi/misi dan komitmen tersebut belum terelasisasi secara maksilmal.

Masalah komitmen atau visi/misi Bupati Yudas Sabaggalet dalam perencanaan RPJMD yang belum terealisasi secara maksimal yang dijelaskan oleh Zulfikar melalui wawancara dengan peneliti:

Untuk masalah komitmen perencanaan pembangunan dari bupati memang sangat penting untuk diperhatikan karena itu merupakan visi/misinya. Salah satunya adalah peningkatan pembangunan infrastruktur untuk meningkatkan akses antar daerah-daerah di Mentawai atau pun antar pulau di Mentawai, ya memang belum bisa semuanya dijalankan oleh Bupati selama dua periode kepemimpinanya. Kemudian, dari sisi pendidikan itu marupakan salah satu program utama beliau untuk meningkatkan SDM di Mentawai masih juga belum mencapai target yang diharapkan, walaupun memang sudah ada peningkatan atau usaha melalui program beasiswa dari pemda yaitu memberikan beasiswa kepada putra putri Mentawai yang tidak punya kemampuan finansial.

Masalah komitmen dari bupati Yudas Sabaggalet mengenai perencanaan RPJMD yang belum terelasisasi secara maksimal dijelaskan juga oleh Yesnimita dalam kutipan wawancara dengan peneliti sebagai berikut:

..Kendalanya bukan berarti tidak kerja secara maksimal, yang menjadi kendalah dalam pembangunan sehingga visi/misi dari Bupati Yudas Sabaggalet tidak berjalan maksimal adalah keterbatasan SDM, karena yang menjalankan atau yang 
bertugas dalam melaksanakan perencanaan pembangunan ini saja SDM-nya masih terbatas. Pengetahuan dan tingkat pendidikan sangat berpengaruh besar berjalannya visi/misi dari pak Yudas Sabaggalet ini.

Dari penejelasan informan tersebut dapat meyakinkan peneliti bahwa selama dua periode kepemimpinan Bupati Yudas Sabaggalet proses perencanaan RPJMD di daerah Kab. Kep. Mentawai masih dalam posisi pendekatan politik, di mana visi/misi atau program pembangunan yang telah ditawarkan selama kampanye maupun setelah terpilih di dua periode diantaranya peningkatan pembangunan SDM dan infrastruktur belum terealisasi secara maksimal, seperti pembangunan infrastruktur-infrastruktur yang meningkatkan akses antar daerah di Mentawai masih belum terelalisasi. Menurut Kuncoro pemilihan presiden/kepalah daerah dipandang sebagai penyusunan rencana karena rakyat memilih menentukan pilihannya berdasarkan program-program pembangunan yang ditawarkan oleh masing-masing calon presiden/kepala daerah.

\section{- Pendekatan Top-Down}

Pada negara dengan sistem pendekatan top-down semua keputusan dan kebijakan yang penting ditentukan oleh pemerintah pusat melalui badan perencanaan pembangunan. Masalah Pendekatan top-down ini tidak hanya terjadi antara pemerintah pusat, tetapi hal ini juga terjadi di pemerintahan daerah pada penentuan dan pelaksanaan kebijakan mengenai visi/misi dan komitmen dari kepalah daerah yang telah dicantumkan dalam dokumen RPJMD selama kampanye maupun setelah terpilih sebagi kepala daerah.

Masalah adanya perencanaan pembangunan yang mengarah ke pendekatan topdown dalam pelaksanaan kebijakan perencanaan RPJMD Kab. Kep. Mentawai diungkapkan juga salah satu anggota DPRD Mentawai Yosep sarokdok melalui wawancara dengan peneliti:

..Terjadi Pro Kontra mengenai BUMD, ketika Bupati mencalonkan diri Tahun 2017, terjadi pula tindakan politisasi kawan-kawan fraksi mengenai RANKERPERDA mengenai BUMD, tidak disetujui oleh fraksi-fraksi lain hanya fraksi PDI-P yang menyejui. Kenapa beberapa program tidak dietujui, karena setelah di disdiskusikan kembali, inikan mau pilkada kalau anggaran dicairkan tentunya anggaran tersebut akan digunakan untuk kepentingan politik.

Diperkuat juga oleh penjelasan salah satu tokoh adat Mentawai Sirilanggai mengenai adanya kebijkan perencanaan RPJMD yang mengarah pada pendekatan topdown, seperti yang dikutip melalui dokumen wawancara dan diskusi dengan peneliti sebagai berikut:

..Masalah tanah adat yang mau dieksekusi di Taileleu, di mana tanah yang mau dieksekusi oleh salah satu anggota DPRD yang bernama adisem (nama yang dikenal oleh masyarakat) ada unsur penipuan dan pembodohan masyarakat di 
dalamnya, katanya tanah tersebut sudah dibeli sekitar seratus hektar, padahal dari pengakuan masyarakat taileleu sebagai pemilik tanah tersebut, tanah yang dibeli hanya sekitar sepuluh hektar saja, tetapi setelah di sidangkan perkara tanah itu, justru anggota DPRD yang bersangkutan mala dimenangkan dalam sidang tersebut" tidak hanya itu beberapa kejadian tentang adanya tindakan pembodohan kepada beberapa tokoh adat maupun kepala dusun yang didekati oleh pejabat, kemudian bernegosiasi masalah lahan, salah satu contohnya adalah eksploitasi besar-besaran hutan di Goisok Oinan oleh aparat polisi dan tentara, hal ini terjadi tanpa sepengetahuan pemilik tanah, cobalah masyarakat yang mengolah hutan tersebut untuk digunakan membangun rumah dibilanglah sama pemerintah itu tindakan illegal, giliran mereka yang ekspolitasi tidak dipermasalahkan oleh pemerintah daerah Mentawai, padahal kami sudah beberapa kali menemui kepalah daerah namun sampai sekarang belum ada kejelasan dan tanggapan serius masalah tanah yang di eksploitasi di Goisok Oinan.

Hal ini meyakinkan peneliti mengenai perencanaan RPJMD cenderung lebih mengarah pada pendekatan top-down, seperti yang didefiiniskan oleh Sjafrizal, pendekatan top-down adalah sistem perencanaan pembangunan di mana kebijakan dalam pembangunan tersebut hanya ditentukan dan diatur serta didominasi oleh pemerintah, seperti halnya yang terjadi di pemerintahan daerah Kab. Kep. Mentawai, di mana kebijakan dan aturan dalam pembangunan hanya ditentukan dan didominasi oleh pemerintah daerah, bahkan peraturan dan kebijakan mengenai visi/misi dan komitmen perencanaan pembangunan dijadikan sebagai alat kepentingan politik.

Fenomena perencanaan RPJMD tersebut menunjukkan bahwa kebijakan dan peraturan lebih mengarah pada pendekatan top-Down. Adanya kebijakan pemerintah daerah Kab.Kep. Mentawai yang mengarah pada pendekatan top-Down, yaitu terjadinya eksploitasi hutan secara besar-besaran di daerah goisok oinan dengan waktu yang cukup lama oleh aparat polisi dan tentara, giliran masyarakat yang mau nebang pohon untuk membangun rumah atau mau membuka usaha kayu, tetapi mala di anggap ilegal oleh pemerintah. Masalah adanya ketimpangan kebijakan seperti ini tidak hanya terjadi di goisok oinan, tetapi juga terjadi dibeberapa tempat di Mentawai seperti Matobe, betumonga, saureinu, katiet dan di Sioban, masalah ini nampak benar benar terjadi ketika peneliti beberapa kali pergi ke kantor bupati, peneliti melihat memang banyak masyarakat daerah Kab. Kep. Mentawai yang mempertanyakan penggunaan tanah mereka yang dieksploitas tanpa ada kesepakatan. Sebenarnya sudah beberapa menemui dan membicarakan masalah lahan/tanah milik masyarakat dengan kepala daerah, namun sudah beberapa kali menjumpai kepala daerah tersebut sampai sekarang belum ada keputusan dan penyelesaian yang jelas. 
Gambar 2. Jalan Matobe Menuju Rokot dan Sioban

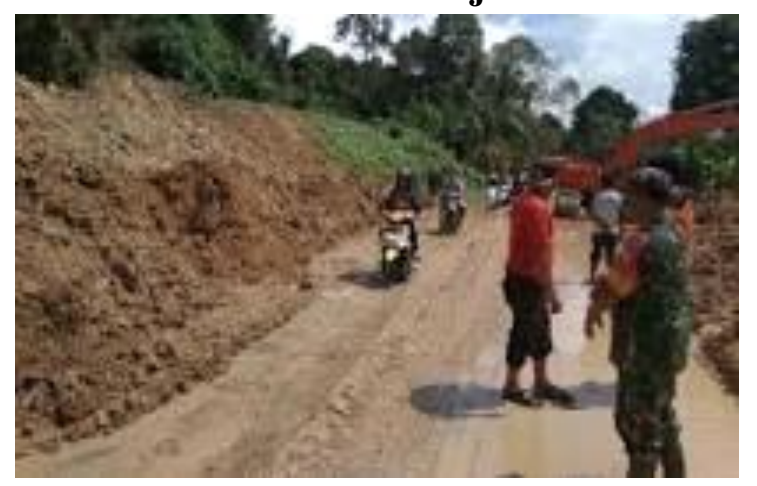

Gambar 3. Jalan Berkat menuju Kecamatan Sipora Utara (Tuapejat) Tahun 2019

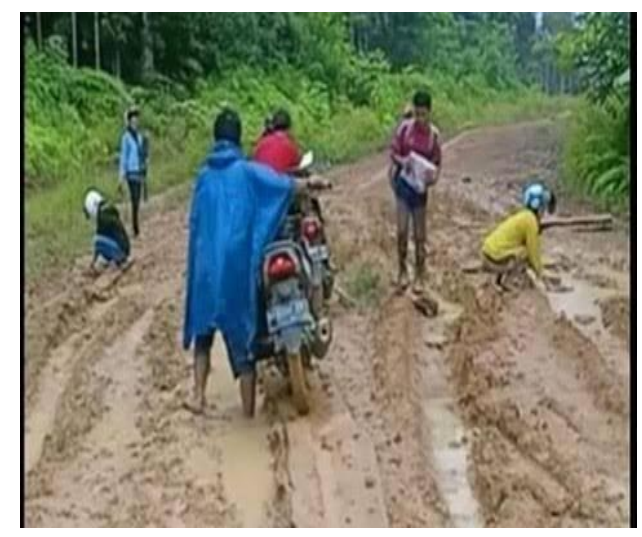

- Faktor Penghambat dalam meningkatkan perencanaan RPJMD dari masyarakat daerah Kab. Kep. Mentawai.

Dalam meningkatkan partisipasi masyarakat supaya terlibat dalam perencanaan RPJMD ada banyak faktor penghambatnya, bisa dari faktor pendidikan atau SDM yang masih rendah sehigga berpengaruh pada pengetahuan dan pemahaman masyarakatnya untuk terlibat dalam perencanaan pembangunan. Faktor penghambat lainnya adalah sikap apatis dari masyarakat yang memang tidak mau tahu dan tidak peduli bagaimana kemajuan pembangunan kedepannya. Kemudian faktor lainnya adalah kurangnya sosialisasi atau pelatihan dari pemerintah daerah kepada masyarakat maupun sesama rekan kerja, dalam memperkenalkan manfaat dan keutungan dari proses perencanaan dan pembangunan. Ada juga dari faktor geografi dan adanya saling tidak percaya antara masyarakat dan pemerintah daerah.

Mengenai faktor penghambat partisipasi dari masyarakat daerah Kab. Kep. Mentawai selama melaksanakan perencanaan RPJMD diungkapkan oleh ketua KNPI Ardiman Saurei sebagai informan triangulasi yang dikutip melalui wawancara dengan peneliti sebagai berikut:

..Masih kurangnya sosialisasi dari Pemda Mentawai dalam memberikan pemahaman tentang pentingnya pembangunan, misalnya pembangunan 
infrastruktur. Masyarakat tidak memahami untuk apa jalan tersebut dibangun, sehingga hal itu menambah masalah baru ketika masyarakat menuntut harus ada ganti rugi dengan alasan kebun atau tanaman yang ditebang sudah sangat merugikan mereka. padahal dalam PP/buku anggaran daerah tidak ada ganti rugi dan kalau disosialisasikan dengan serius, bahwasannya dengan adanya jalan akan melancarkan juga anak-anak mereka pulang balik sekolah tidak perlu lagi melalui jalur laut. Contohnya di kampung Sagitci, ketika dilakukan siosialisasi dengan serius masyarakat disana ternyata sangat terbuka dan mengharapkan adanya jalan.

Kemudian masalah faktor penghambat dalam melaksanakan perencanaan RPJMD di mentawai sendiri dijelaskan juga oleh Zulfikar dalam dokumen wawancara degan peneliti:

..Kalau di Mentawai sendiri yang menjadi faktor penghambat partisispasi dari masyarakat untuk terlibat dalam perencaan pembangunan dipengaruhi juga oleh masalah rendahnya SDM. Kurangnya SDM sangat berpengaruh pada pengetahuan dan pemahaman masyarakat untuk membedakan mana yang menjadi kebutuhan dalam pembangunan dan mana yang hanya sekedar menjadi keinginan. Mereka melihat ditempat lain mendapatkan bantuan mereka juga ingin mendapatkan bantuan tersebut padahal tidak sesuai dengan kebutuhan mereka. :

Kemudian miskominakasi yang terjadi selama pelaksanaan perencanaan RPJMD yang diungkapkan juga oleh elvi dalam dokumen wawancara dengan peneliti sebagai berikut:

..Miskomunikasi yang sering kali terjadi adalah ketika dalam penyampaian laporan yang ada kaitannya dengan proses pelaksanaan perencanan pembangunan, sehingga berakibat pada pelaksanaan pembangunan nantinya. Kemudian miskomikasi juga sering kali terjadi karena ketika di adakan rapat atau kegiatan musrenbang beberapa OPD tidak datang dalam kegiatan tersebut.

Dapat dijelaskan bahwa yang menjadi faktor peghambat dalam perencanaan RPJMD adalah sering terjadinya miskomunikasi antara perangkat daerah, dikarenakan kurangnya pemahaman pelaksanaan tugas, hal ini berhimbas pada keterlambatanketerlambatan dalam pelaksanaan tugas masing-masing. Tidak hanya itu saja masalah miskomikasi juga terjadi dalam penyampaian laporan, yang berrdampak pada pelaksanaan perencanaan pembanguan kedepan. Miskomikasi dalam perencanaan pembangunan partisipatif juga disebabkan karena pada kegiatan rapat atau, musrenbang beberapa OPD tidak datang.

Dari temuan peneliti dilapangan yang menjadi faktor penghambat perencaaan pembangunan RPJMD memang faktor utamanya adalah keterbatasan SDM, baik SDM dalam pemerintah maupun masyarakatnya itu sendiri. Keterbatasan SDM juga 
berpengaruh pada kesadaran dan pengetahuan baik pemerintah dan masayarakat dalam menjalankan dan terlibat dalam perencanaan RPJMD. Hal ini senada dengan apa yang disampaikan oleh Santoso Satropoetro, bahwa yang menjadi faktor penghambat dalam proses perencanaan pembangunan partisipatif adalah rendahnya kualitas pendidikan dan tingkat pendapatan yang rendah. Walaupun memang ada beberapa temuan peneliti yang baru di lapangan mengenai apa yang menjadi faktor penghambat perencanaan pembangunan partisipatif dalam RPJMD di Kap. Kep. Mentawai.

\section{KESIMPULAN}

Perencanaan pembangunan pada dasarnya merupakan suatu tahapan, cara, teknik atau metode untuk mencapai tujuan yang diinginkan secara tepat, terarah dan efisien sesuai dengan sumber daya yang tersedia. Salah satu Kabupaten yang melaksanakan perencanaan RPJMD adalah Kab. Kep. Mentawai. perencanaan RPJMD di Kab. Kep. Mentawai memang sudah dimulai, akan tetapi hasilnya belum sesuai dengan harapan, seperti melibatkan partisipasi masyarakat.

Persoalan perencanaan RPJMD yang masih dalam posisi pendekatan politik terdiri dari beberapa program dan visi/misi Bupati Yudas Sabaggalet salama kampanye dan setelah terpilih, diantaranya program peningatan SDM dan peningkatan Infrastruktur yang dijadikan sebagai kepentingan politik. Tidak hanya itu, perencanaan pembangunan pendekatan politik dalam penerapan visi/misi lebih cenderung dan didominasi oleh pendekatan Top-Down, karena banyaknya masyarakat yang tidak percaya dan merasa kecewa pemerintah daerah Kab. Kep. Mentawai. Program perencanaan RPJMD yang ditawarkan kesannya untuk meningkatkan keadilan dan kesejahteraan masyarakat, sementara fakta yang dirasakan masyarakat bukanlah demikian. Kebijakan dan komitmen maupun visi/misi dari Bupati lebih didominasi oleh pihak-pihak yang menjadikan visimisi tersebut sebagai kepentingan politik, pribadi maupun golongan.

\section{DAFTAR PUSTAKA}

\section{Buku}

Afrizal. 2014. Metode Penelitian Kualitatif: Sebuah Upaya Mendukung Penggunaan Penelitian Kualitatif Dalam Berbagai Disiplin Ilmu. Jakarta: Rajawali Pers.

Asrinaldi. Politik dan Pemerintahan di Sumatera Barat. Padang: Erka CV. Rumahkayu Pustaka Utami.

Ali Kabul Mahi \& Sri Indra Trigunarso. 2017. Perencanaan Pembngunan Daerah (Teori dan Aplikasi). Bandar Lampung: Kencana.

Burhan Bungin. 2017. Penelitian Kualitatif: Komunikasi, Ekonomi, Kebijakan Publik, dan Ilmu Sosial Lainnya. Jakarta: Kencana. 
Danu Eko Agustinova. 2015. Memahami Meotode Penlitian Kualitatif: Teori \& Praktik. Yogyakarta: Calpulis.

Henk Schulte Nordholt, Gerry Van Klinken dan Ireen Karang- Hoogenboom. 2007. Politik Lokal di Indonesia. Jakarta: Yayasan Obor Indonesia.

Koentjaraningrat. 2004. Kebudayaan Mentalitas dan Pembangunan. Jakarta: PT Gramedia.

Mudrajad Kuncoro. 2018. Perencanaan Pembangunan Daerah; Teori dan Aplikasi. Jakarta: PT Gramedia Pustaka Utama.

Robert K Yin. 2015. Studi Kasus: Desain \& Metode. Jakarta: Rajawali Pers.

Sjafrizal. 2017. Perncaan Pembangunan daerah Dalam Era Otonomi. Depok: Rajawali Pers.

Sjafrizal. 2019. Teknik Penyusunan Rencana Pembangunan Daerah. Jakarta: Badaouse Media.

Sugiyono. 2014. Metode Penelitian Kuantitatif Kualitatif dan R\&D. Bandung: Alfabeta.

Warjio, Ph.D.2016. Politik Pembangunan: Paradoks, Teori, Aktor \& Ideologi. Medan: Kencana.

\section{Jurnal}

Adriani Ginting, Bambang Supriyono, Irwan Noor. 2016. "Perencanaan Pembangunan Daerah Dalam RangkaMeningkatkan Daya Saing (Studi Pada Provinsi Bengkulu)" Vol 19. No (1). Jurnal Wacana, 56-59.

Herendhika Lukiswara. 2016 "Analisis Perencanaan Pembangunan Daerah Dengan Pendekatan Sistem Lunak di Kabupaten Trenggalek" Vol. 2 Nomor (4) Jurnal Ilmiah Administrasi Publik pp . 216-226.

Aziz Muslim. 2017 "Pendekatan Partisipatif Dalam Pemberdayaan Masyarakat" (https://fdokumen.com (Category Documents). Viol 1. No (1). Jurnal Pengembangan Masyarakat Islam (PMI). hal. 80-103.

H Ahmad Mustanir, Akhmad Yasin. 2018 “ Partisipasi Masyarakat dalam Transect pada Perencanaan Pembangunan”'Jurnal Ilmiah Ilmu Administrasi Publik: Jurnal Pemikiran dan Penelitian Administrasi Publik,1-2.

Ita Puspita Sari. 2016. "Implementasi Pembangunan Parsipatif (Studi Kasus di Kelurahan Andowia Kabupaten Konawe Utara)"). Vol .1 No (1), Jurnal Ekonomi (JE), 181. 
Muhammad Wahyuddin. 2016 ."Evaluasi Pelaksanaan Rencana Pembangunan Jangka Menengah Daerah (RPJMD) Kabupaten Berau Tahun 2010- 2015 Bidang Pendidikan Dan Bidang Kesehatan”. Journal S Saleh

Nabila Zatadini, Sri Sulastutu, Eka Deviani. 2018, Peran Badan Perencanaan Pembangunan Daerah Dalam Peningkatan Percepatan Pembangunan di Kabuaten Lampung.

Nona R. Majore, Welson Y. Rompas, Rully Mambo. "Koordinasi Pemerintah Daerah Dalam Pembangunan Jalan di Kecamatan Salibbabu kabupaten Kepulaan Talaud". https://www.neliti.com/id/publications/73443, 1-18.

Ricky wirawan. 2015."Partisipasi Masyarakat Dalam Perencanaan membangunan Daerah”. Jurnal Ilmu Sosial dan Ilmu Politik, 301-309.

Robert K. Yin . 2009. Case Study Research Design and Methods, Sage, ThousandOaks, CA.pdf. California: SAGE Publication Inc.

Samsulhadi, SH, MH., 2017. Perencanaan Pembagunan Daerah Dalam Pandangan Asas-Asas Penyelengaraan Pemerintah. 